\title{
THE APPLICATION OF RIDDLE GAME IN TEACHING SPEAKING FOR THE EIGHTH GRADE STUDENTS OF MTsN KEDUNGGALAR NGAWI IN THE SCHOOLING YEAR 2014/2015
}

\author{
Minda Tika Hapsari \\ Fitra Pinandhita \\ IKIP PGRI MADIUN
}

\begin{abstract}
Riddle game is one of the good techniques in teaching speaking. The objectives of this research are to describe the application of riddle game in teaching speaking, identify the advantages, identify the disadvantages and identify the solution of disadvantages of riddle game.
\end{abstract}

The researcher uses descriptive qualitative research. The sources of data taken from participants, social situation and document. In this research, the researcher uses purposive sampling. To collect the data, there are observation, interview and documentation. Data validity is triangulation. The data are analyzed by using condensation, display the data, verification and conclusion.

The result of this research are (1) the application of riddle game in teaching speaking is divided into three steps: (a) pre-activities (b) whilst-activities (c) post-activities (2) The advantages of riddle game in teaching speaking makes the students active in learning process, happy, increase their vocabulary, able to pronounce some words well and confident to retell the story (3) The disadvantages: makes the class crowded and riddle game has limited time (4) The solution of disadvantages of riddle game is the teacher can manage the time well and able to control the students well in order to make a good atmosphere of the class.

Key Term: Speaking, Riddle game

\section{INTRODUCTION}

English language has four basic skills, which have to be mastered by people who learns English. There are reading, listening, writing and speaking. It means that those four skills are important to be taught in teaching and learning process.

Speaking is an important skill because one of the keys in English communication is speaking ability. According to Nunan (2003: 48), "Speaking is the productive aural/ oral skill". It means that speaking is oral skill that used people to speak up.

Teaching speaking is not easy. There are many problems in teaching speaking. In fact, the problems come from students and teacher. The students' problems are: first, the students lack of vocabulary. 
Second, most of students are not confident to use English in speaking class. Third, the students do not know a good pronounciation when they speak English. Last, the students often to use Javanese or Indonesian in language.

Then, the teacher's problems are: first, The teacher still uses traditional method in teaching speaking. Furthermore, the teacher just gives the materials without any explanation. Second, the teacher still uses Javanese or Indonesian language when they teach. Third, the teacher sometimes cannot manage the class well. So, the class is crowded. Last, the teacher do not use various media in teaching speaking.

Based on the problems above, to solve that problems the teacher finds a new way in teaching speaking. One of the ways to solve the problems is using riddle game. Riddle game is important in teaching speaking because it gives students an opportunity to practice communicating in different ways. According to Sharndama and Magaji (2014: 2), "Riddles are puzzled descriptive statements or direct questions demanding the answerer to provide the association or connotation". It means that riddle is puzzle game with direct question to answer the question. Riddle game has some benefits, they are: first, introduce to the students the intellectual humor. Laughter is important to happiness and health. In addition, laughter is a very good way to motivate people. Second, the students' brain can work well. Third, expand students' vocabulary.

From the explanation above, the researcher conduct the research entitled "The Application of Riddle Game in Teaching Speaking for the Eighth Grade
Students of MTSN Kedunggalar Ngawi in the Schooling Year 2014/2015".

There are four problems statement in this research. The first, how is the application of riddle game in teaching speaking for the eighth grade students of MTsN Kedunggalar Ngawi in the schooling year 2014/2015.

Second, what are the advantages of riddle game in teaching speaking for the eighth grade students of MTsN Kedunggalar Ngawi in the schooling year 2014/2015. Third, what are the disadvantages of riddle game in teaching speaking for the eighth grade students of MTsN Kedunggalar Ngawi in the schooling year 2014/2015. Fourth, what is the solution of disadvantages of riddle game in teaching speaking for the eighth grade students of MTsN Kedunggalar Ngawi in the schooling year 2014/2015.

\section{THEORETICAL FRAMEWORK.}

\section{Teaching Speaking}

In this part, the researcher presents about teaching speaking. According to Hughes (2002: 6), “Teaching speaking is not easily separated from other object. A further complicating factor is that when the spoken language is the focus of classroom activity there are often other aims which the teacher might have, for instance, helping the students to gain awareness of or to practice some aspect of linguistic knowledge. The activities of teaching speaking are: discussion, role play, simulation, information gap, song, storytelling, interview, brainstorming, games, picture- based activities for speak 


\section{Riddle Game}

The definition of riddle game is game will be use in this research. According to Isbell and Fernandez (1977: 2) "Riddle are verbal play which involve puzzling about "what is like what". It means that riddle is verbal game by using puzzle. In other hand, the expert also gives quotes. According to Sharndama and Magaji (2014:2), "Riddles are puzzled descriptive statements or direct questions demanding the answerer to provide the association or connotation". It means that riddle is involves language manipulation by the questioner in order to confuse the answerer. From the theories above, it can be concluded that riddle is describe question in puzzle form to solve guessed by using verbal language.

\section{Procedure to Play Riddle Game}

Many procedure to play riddle game, one of them based on Lewis (2012: 3 ) state that there are some procedure to play riddle game.

a. Tell your students that the riddle is about a person, place, animal, or thing.

b. Write the vocabulary that you believe they don't know on the board and go over the meanings within the context of how they're used in the riddle. Do not put words on the board that will give away the answer.

c. After getting the vocabulary out of the way, do the dictation line-by-line. See Dictation Patterns for two possible patterns. At this time do not let anyone give the answer.

d. As the dictation progresses, keep reminding them not to give the answer, although you can let them say, "Teacher, I know."

e. When you reach the last line, dictate the first part of the line and then ask, "Who knows the answer?" If the students disagree with each other, discuss the answers. If no one knows, give the answer and consider having them do some followup research.

\section{RESEARCH METHODOLOGY}

\section{Place and Time of the Research}

The research is held in MTsN

Kedunggalar Ngawi. The researcher chooses MTsN Kedunggalar Ngawi as the place of the research because MTsN Kedunggalar Ngawi has complete facility, have difficulties in speaking ability and MTsN Kedunggalar Ngawi applies riddle game as media in teaching and learning activity. This research will be done for five months. The research was started on February-July, 2015.

\section{Approach and Types of Research}

In this research, the researcher uses qualitative research. According to Bogdan and Biklen (2007: 54) states that qualitative research proceed as if they know very little about the people and places they will visit. It means that qualitative research is process collecting data based on the people and places when the researcher doing observation. Qualitative research is research how people life every day in real world. This case, the researcher uses descriptive qualitative research. According to Bogdan and Biklen (2007: 5), "Qualitative is descriptive. The data collected take the form of words or pictures rather than number". It means that qualitative 
descriptive is the collecting data of words or pictures rather than number. Qualitative descriptive is the collecting data from of words or pictures rather not numbers and includes surveys and fact finding enquires of different kinds.

\section{Data Resources}

The researcher needs source of data to support the research. The source of data are social situation, participants and document. The first is social situation, the social situation in this research, the researcher observe the place, actor and activity in application of riddle game in teaching speaking for the 8A grade students of MTsN Kedunggalar Ngawi in the schooling year 2014/205. The second is participants, the participant of the research are the teacher and $8 \mathrm{~A}$ grade students of MTsN Kedunggalar Ngawi in the schooling year 2014/2015. The last is document, document is data which is gather to analysis in this research. The source of document includes: syllabus, rpp (lesson plan), picture and so on.

\section{Techniques of Collecting Data}

In this research, the researcher uses observation, interview and documentation to collecting data. First is observation, observation is method of collecting data which is done by researcher by hearing or seeing the phenomenon that happen in the field research. In this research, the researcher observes the teacher and students in teaching speaking by using riddle game of $8 \mathrm{~A}$ grade students of MTsN Kedunggalar in the schooling year 2014/2015.the result of the interview to answer the problems of statement. Second is interview. Interview to describe the data and interpret the subject by using the researchers' own word. The researcher asks the object of research to interview that is focused on question related to researcher study. In this research, the researcher does interview with the teacher and 8A grade students of MTsN Kedunggalar. Third is documentation. Documentation as content analysis is not limited to written or printed document but extent as well to audio recording, still photograph, mention-picture film, video recording and the like. This research, the researcher uses document and photo to get data, such as picture, RPP, syllabus, students' score, and student's name list.

\section{Research Procedures}

Research procedures in this research include of planning or preparation, application and reporting.

1. Preparation (choosing the location, getting the license, asking permission, observing the class and preparing the instruments).

\section{Application (collecting the data and analyzing the data).}

3. Reporting (the researcher makes a report and analyzes the data that have collected).

\section{Data Validating Techniques}

In this research, the researcher uses triangulation. According to Sugiyono (2013: 327), "Triagulasi diartikan sebagai teknik pengumpulan data yang bersifat menggabungkan dari beberapa teknik pengumpulan data dan sumber yang telah ada". It means that triagulation is data collecting technique by combining some source of data. In this research, the researcher uses the several of data such as observation, interview, and documentation. 


\section{Data Analyzing Technique}

Data analysis is used in this research. There are three types to collect data analysis, data analysis consist of condensation, displaying data and verification.

\section{Condensation}

Data condensation refer to the process of selecting, focusing, simplifying, abstracting, and transforming the data that appear in written-up field notes, interview, transcrips, documents and other empirical materials.

\section{Displaying Data}

The notion of data display is intended to convey the idea that data are presented as an organized, compressed assembly of information that permits conclusions to be analytically drawn. The researcher needs to display the data in order to give clear description:

a) The data from observation is about the application of riddle game in teaching speaking for the eighth grade students of MTsN Kedunggalar Ngawi.

b) The data from interview is about the problem in teaching speaking and the solving of the problem in teaching process.

c) The data from documentation is about the condition of the classes using riddle game in teaching speaking for the eighth grade students of MTsN Kedunggalar Ngawi..

3. Verification or Conlusion

In collecting the data, the resercher should make conclusion the data found. Conclusion and verification used by researcher to conclude and verify the research result. In this step, the researcher sum up the procedures, the advantages, disadvantages and solutions of the disadvantages of the application of riddle game in teaching speaking for the eighth grade students of MTsN Kedunggalar in the schooling year 2014/2015.

\section{DISCUSSION}

\section{The Application of Riddle Game in} Teaching Speaking for the Eighth Grade Students of MTsN Kedunggalar Ngawi in the Schooling Year 2014/2015

Based on the research, the research apply the application of riddle game in teaching speaking for the eighth grade students of MTsN Kedunggalar Ngawi in the schooling Year 2014/2015 are done in two steps. The first steps is preparation, the teacher prepares syllabus and lesson plan. Syllabus and lesson plan helps the teacher to decide kinds of material that she gives to students. In this step, the teacher prepares the worksheet as assignment to students for measuring their understanding about the material given. She also prepares riddle game to support this game. The second steps is teaching and learning process. In teaching process the teacher gives facilitation to the students by using riddle game as media. The teacher also guides the students to use this media in learning process. The learning activities of teaching speaking by using riddle game are divided into three steps, they are: Preactivities, Whilst-activities, Post-activities. The activities will be discussing bellows: 
Pre-Activities

The first activities are pre activities. The teacher starts the meeting by greeting the students. Then, the teacher calls the students' name one by one to show his presence. After that, the teacher gives motivation to make students concentration during learning process. Next, the teacher relates the material that will be learnt with the previous material. The students pay attention and respond to the teacher. These activities are aimed to motivation the students to able following the lesson well. In addition, the teacher gives brainstorming to know what materials will be discussed. Last, the teacher mentions the purposes of the learning process

\section{Whilst-Activities}

The second activities is whilst activities. The steps are explained below: the teacher gives narrative text "Timun Mas" and the students must read together. After that, the teacher explains the procedures of riddle game. It is related to Lewis (2012: 3), “

a. Tell your students that the riddle is about a person, place, animal, or thing.

b. Write the vocabulary that you believe they don't know on the board and go over the meanings within the context of how they're used in the riddle. Do not put words on the board that will give away the answer.

c. After getting the vocabulary out of the way, do the dictation line-by-line. See Dictation Patterns for two possible patterns. At this time do not let anyone give the answer. d. As the dictation progresses, keep reminding them not to give the answer, although you can let them say, "Teacher, I know."

e. When you reach the last line, dictate the first part of the line and then ask, "Who knows the answer?" If the students disagree with each other, discuss the answers. If no one knows, give the answer and consider having them do some followup research.

It is supported by teacher's interview. She says, "Prosedure pembelajaran speaking dengan menggunakan riddle game itu dimulai dari guru harus menyiapkan materi seperti text dan riddle game dulu mbak, terus guru memberikan pertanyaan ke siswanya tentang teks tersebut dan siswa menulis jawaban dalam riddle sesuai kotaknya. Siswa yang benar menjawab akan mendapatkan score untuk memotivasi biar lebih aktif mbak dan yang nilainya tinggi akan menjadi pemenang dan mendapat hadiah. Itu prosedur dalam pembelajaran speaking mbak". It means that, the procedure from theory irrelevant with the teacher's procedure when the teacher applying the riddle game. Based on the researcher's observation, the causes are: the knowledge of the teacher and the condition of the students. Many theory unrelated when the teacher to apply the game, it caused many factors as mentioned above. Based on the research, if the theory unrelated with the application in real condition, it called a new discovery, we as researcher has the idea to combine this theory with different application to make students more easy to understanding the lesson by using a riddle game. Then the teacher explains the material about generic 
structures. There are consisting of orientation, complication, resolution and re-orientation. After that, the teacher asks the students to identify the text based on the generic structure. Then, the teacher gives task to students. They work their task by using riddle game. the students who has high score, they get reward from the teacher and last meeting, the student must telling the story about Timun Mas in front of class one by one.

Post-Activities

In the last step, the teacher gives evaluation about the learning process. The teacher and the students summarize the material that they have learned. The teacher also asks the students' difficulties about the material. The last, the teacher closes the meeting.

The Advantages of Riddle Game in Teaching Speaking for the Eighth Grade Students of MTsN Kedunggalar Ngawi in the Schooling Year 2014/2015

There are some advantages of riddle game in teaching speaking for the eighth grade students of MTsN Kedunggalar Ngawi in the schooling year 2014/2015. They are:

a. Riddle game can increase the students' interest to learning speaking.

b. The students are happy in learning narrative text by using riddle game.

c. The students can increase their vocabulary by using riddle game.

d. The students' active in learning process.

e. The students pronounce some words well. f. The students are confident to retell story.

The disadvantages of Riddle Game in Teaching Speaking for the Eighth Grade Students of MTsN Kedunggalar Ngawi in the Schooling Year 2014/2015

There are some advantages of riddle game in teaching speaking for the eighth grade students of MTsN Kedunggalar Ngawi in the schooling year 2014/2015. They are:

a. Riddle game makes the class crowded

b. Riddle game has limited time

c. Many vocabularies cannot write in this riddle, it makes students difficult to retell the story

The Solution of disadvantages of Riddle Game in Teaching Speaking for the Eighth Grade Students of MTsN Kedunggalar Ngawi in the Schooling Year 2014/2015

There are some solutions of disadvantages of riddle game in teaching speaking for the eighth grade students of MTsN Kedunggalar Ngawi in the schooling year 2014/2015. They are:

a. The teacher controls the students well to make the class conducive.

The solution of disadvantages of riddle game is the teacher controls well the students to make the class conducive. If the class conducive and silent, the objective of learning process can be reached suitable the lesson plan. It means that the teacher as controller should control every process. It is used to solve the first disadvantage. 
b. The teacher manages the time well before applies this game.

The second solution of disadvantages is the teacher manages the time well because if the game cannot finish based on schedule it makes the students difficult in following the lesson. The students' difficulties in understanding the material, playing the game and so on. It is used to solve the second disadvantages.

c. The teacher makes bigger riddle. So, many vocabularies showed in that game

The third solution of disadvantages, the teacher makes the bigger riddle. So, many vocabularies showed in the riddle.. The bigger riddle makes the students confident to retell the story because many vocabularies showed in the riddle and students easy to telling the story. It is used to solve the third disadvantages

\section{CONCLUSION}

The application of riddle game in teaching speaking for 8A grade students of MTsN Kedunggalar Ngawi in the schooling year 2014/2015 is done in two main steps. They are preparation and teaching learning process. In the preparation, the teacher prepares syllabus, lesson plan and students' worksheet. Then, in the teaching learning process, there are pre-activities, while-activities and postactivities.

The advantages of application of riddle game in teaching speaking for 8A grade students of MTsN Kedunggalar in the schooling year 2014/2015 are: (1) Riddle game can increase the student's interest to learning speaking, (2) riddle game makes students happy in learning narrative text by using riddle game, (3) the students can increase their vocabulary when they learn by using riddle game. Riddle game makes the students more interested when they learn vocabulary, (4) the students are active in the learning process, (5) the students pronounce some words well, (6) The students are confident to retell the story.

The disadvantages of application of riddle game in teaching speaking for 8A grade students of MTsN Kedunggalar in the schooling year 2014/2015 are: (1) riddle game makes the class crowded, (2) riddle game has limited time, (3) many vocabularies cannot written in this riddle, it makes students difficult to retell the story.

The solution of the disadvantages of application of riddle game in teaching speaking for 8A grade student of MTsN Kedunggalar in the schooling year 2014/2015 are: (1) the teacher controls the students well to makes the class conducive, (2) he teacher manages the time well before applies this game, (3) the teacher makes bigger riddle. So, many vocabularies showed in that game.

\section{REFERENCES}

Bogdan, R., \& Biklen, S. (2007). Qualitative research for education: An introduction to theories and methods (5th ed). Boston, Mas.: Pearson A \& B.

Isbell, B., \& Fernandes, F. (n.d.).The Otogenesis of Metaphor: Riddle Game among Quechua Speakers Seen as Cognitive Discovey Procedure,3(1), 19-49.

Lewis, J. (2012). Pro Lingua's Books / Dictation Riddles. Retrieved July 9, 2015, from 
http://www.prolinguaassociates.com/Dicta tion_Riddles/index.html. (2003). Practical English Language Teaching. New York: MC Graw Hill.
Sharndama, E., \& Magaji, M.

(2014).Morphology, Syntax and Functions of Kilba Folk Riddles,2(4), 1-12.

Sugiyono. 2013. Metode Penelitian

Pendidikan. Bandung: Alfabeta 